\title{
Panorama Geral
}

\section{Overview}

\section{Matheus Abel Lima de Bitencourt}

É artista visual e mestrando em Processos Artísticos Contemporâneos na UDESC. Investiga processos de escrita e modos de leitura. Pensa o pensar o processo enquanto obra talveztenhaavercomarte@gmail.com - https://orcid.org/0000-0002-2214-4377

\section{Resumo}

Panorama Geral

Palavras-chave Cartografia na arte. Escrita e arte. Artes cênicas. Performance (Arte)

\section{Abstract}

Overview.

Keywords: Cartography in art. Writing and art. Artes cênicas. Performance art 
PANORAMA GERAL

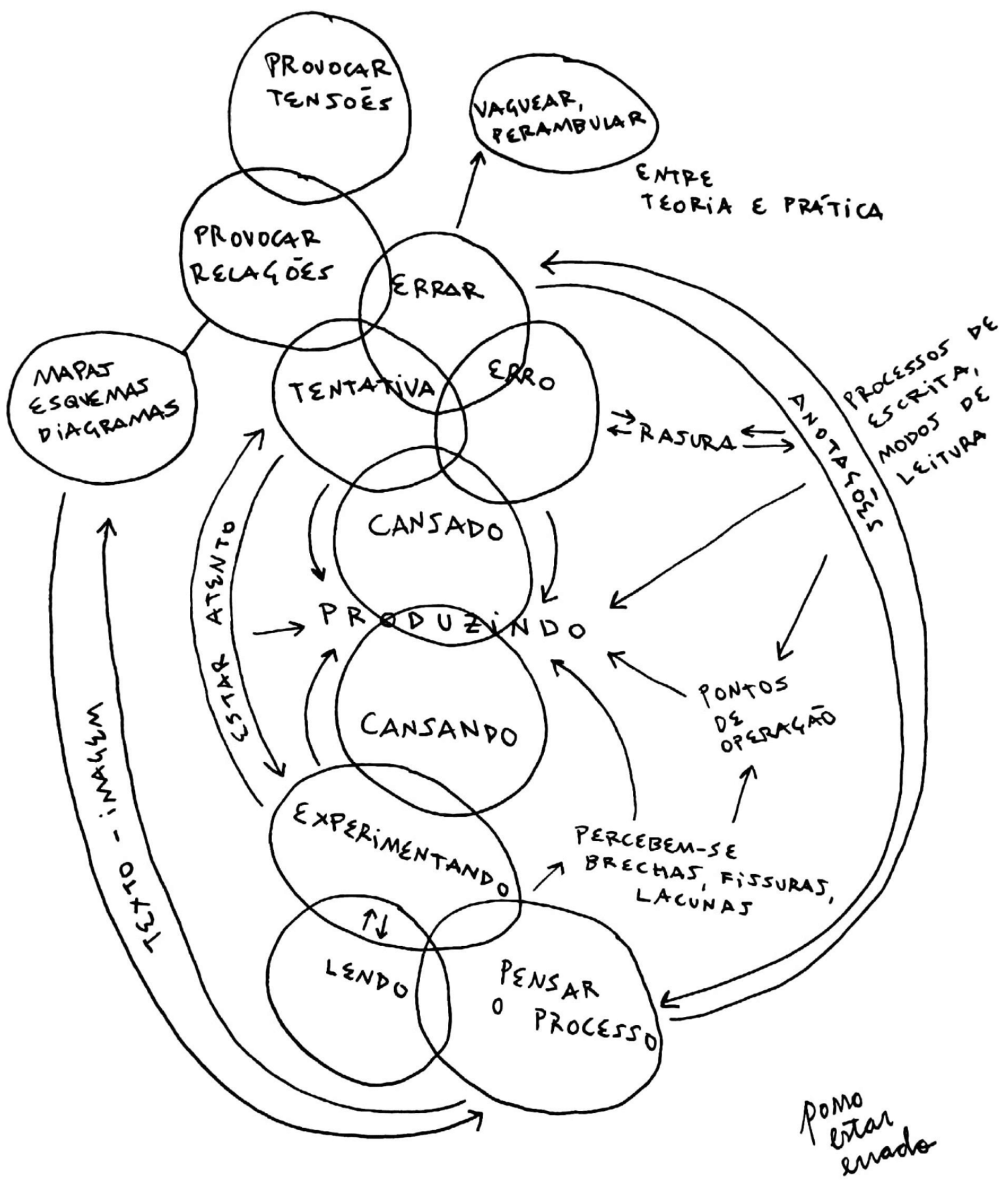

DAPesquisa, Florianópolis, v.15, out. 2020. Escrita Performativa, p. 02-05.

DOI: http://dx.doi.org/10.5965/1808312915252020e0028 
Pensado de dentro do arranjo maquínico do dispositivo diagrama, bem como a partir dele e sobre o mesmo, Panorama geral sintetiza uma série de imagens produzidas anteriormente, em 2018 e 2019, em uma só. Operando em um dos inúmeros pontos de intersecção entre texto+imagem, verbo+visual, enunciado+visualidade, esse textodesenho discute o processo sobre si, investigando sua própria construção e feitura.

Percebe-se o produzir num entre do cansaço e estar cansando, pontos de onde se desdobram outros momentos do fazer, investigar, errar (desde a rasura até a errância). Os pontos de intersecção entre dois ou três campos são deixados em branco - não inexplorados, mas talvez incertos, oscilantes, aguardando algo que os atravesse ou anule: são vazios e potências, ao mesmo tempo.

Nada na imagem+texto tende ou pretende a induzir o olhar de quem vê+lê, afim de que nada the seja entregue mesmo que minimamente pré-elaborado. Tampouco apresenta alguma metáfora: mas mantém-se aberto para que cada visualizador+leitor use o texto e estabeleça suas próprias relações. Uma vez que o diagrama trata não apenas do processo de produção em artes visuais, mas de um dos possíveis processos, assume novamente o papel da arte, como dito pelo artista conceitual Lawrence Weiner: sendo uma apresentação, nunca uma imposição; e pelo também conceitual John Baldessari: abundantemente simples e enlouquecedoramente complexo. 
Toda a investigação proposta por essa série de trabalhos, aqui disposta e organizada em um único panorama, opera os inúmeros pontos de intersecções entre teoria e prática. Observando os horizontes de ambos os lados percebo que começam pelo meio, como coloca Lancri em seu texto-fala, e penso o meio aqui como ateliê: um ponto inicial de observação das camadas que se sobrepõem; de mergulho no coeficiente de arte de Duchamp; de desdobramentos, pensatas, cruzamentos. Ou como propõe Deleuze, rizomas atemporais, que se conectam e que não têm como fixo de um ponto e outro, se traça no caminhar e na experiência. 


\section{REFERÊNCIAS}

ABEL, M. Portfólio Matheus Abel: portfólio a partir da série Mapas/Esquemas/Diagramas, 2018-2020. \{S. I. : s. n.], maio 2020. ISSUU: matheus.abel . Disponível em:

https://issuu.com/matheus.abel/docs/portf_lio_matheus_abel. Acesso em: 27 jun. 2020. 